\title{
Living on edge: New perspectives on anxiety, refuge, and colonialism in southern Africa
}

\author{
Rachel King ${ }^{1,2,3}$ \\ ${ }^{1}$ Centre of African Studies, University of Cambridge \\ ${ }^{2}$ McDonald Institute of Archaeological Research, University of Cambridge \\ ${ }^{3}$ Rock Art Research Institute, University of the Witwatersrand
}

Corresponding author: rk547@cam.ac.uk

\begin{abstract}
Archaeologies of colonialism have have called for exploring the culturally dynamic entanglements of people and objects while acknowledging the violence that accompanied these entanglements. Heeding these calls requires attention to how the state and state power were materialised, particularly in settler colonies where state apparatuses advanced unevenly, insidiously, and clumsily. Here, I explore how the (mis)understandings and (mis)apprehensions of people and places that accompanied the halting expansion of colonial frontiers were materialised. Focusing on southern Africa's Highveld and Maloti-Drakensberg Mountains, I offer anxiety as a framework for conceiving of colonialisms as epistemic encounters: processes of 'making sense' of new people, things, and places based on material practices, empirical experience, and desire. Through a narrative of the nineteenth-century Maloti-Drakensberg told with archival, archaeological, and ethnographic materials, I re-visit a longstanding trope of southern African archaeology and historiography: refugia from social distress. I argue that refuge can be taken as a sense-making practice rather than as reaction to stress. I close with thoughts on what an anxiety framework can offer the still-developing field of African historical archaeology.
\end{abstract}

Keywords anxiety, resistance, southern Africa, colonialism, Maloti-Drakensberg

\section{Author's biographical note}

Rachel King is the Smuts Research Fellow in African Studies at the Centre of African Studies, University of Cambridge, and an Honorary Research Fellow at the Rock Art Research Institute, University of the Witwatersrand. Her doctoral thesis (University of Oxford) was an historical and archaeological study of the BaPhuthi chiefdom in nineteenth-century Basutoland and the eastern Cape. Her current research concerns cattle-keeping and raiding in Maloti-Drakensberg lifeways and cosmologies over the last millennium, and the relationship between heritage management and dam building in Lesotho. 


\section{Introduction}

Imperatives to recover archaeological perspectives on colonialism have spurred the formation of a vast array of methodological and theoretical toolkits, tailored to the conflicted terrain of what are today sensitive post-colonial contexts (Voss \& Casella 2012). I say 'imperatives' because in these contexts - especially in Africa - archaeological treatments of colonialism do not just provide another body of evidence for an already heavily researched topic: they shape discourse about a past and present situated amidst the lingering impacts of hegemonic projects (Giblin et al. 2014; Lane 2011; Shepherd 2004). Care and precision with our methodologies and vocabulary is therefore key. Studies of culture contact and colonialism have provided us with an extensive lexicon of terms for discussing the dynamics of these encounters: resistance, accommodation, acculturation, entanglement, and on seemingly ad infinitum. Archaeological conceptions of colonialism as different sorts of entanglements - in which objects enter new regimes of value as they circulate through new encounters - offer views of cultural creativity, resilience, and means of rectifying silences and discrepancies between written and material records (e.g. Thomas 1991; Stahl 2001; Gosden 2004; Silliman 2005; cf. Voss 2015).

Recently, some have advocated approaches that acknowledge more explicitly the violence and trauma that accompanied colonial expansion (cf. Haber 2009). Alfredo González-Ruibal (2014) has offered a compelling reading of the historical experiences of egalitarian societies in the Horn of Africa and Sudan that foregrounds the perceptions of peoples oppressed by the state. González-Ruibal's discussion articulates the 'ontologies of resistance' developed through these societies' sustained marginalisation. Archaeologies of subjugated peoples living 'in the face of the state' invite us to re-consider or make space within colonialism-asentanglement for acknowledging that 'colonialism was as much a creation of rogues and independent agents as it was the product of imperial states' (Dawdy 2008, 19). Writing from the perspective of French colonial New Orleans, Shannon Lee Dawdy (ibid.) has cogently observed that "'colonial power" has become too abstracted and overstated' - a hegemonic juggernaut that in some archaeological interpretations may appear overdetermined or omnipresent. Dawdy encourages archaeologists and historians alike to re-focus attention on the individuals and, importantly, the kinds of individuals - engineers, creoles, smugglers that manipulated the state to re-fashion and re-interpret colonialism at a local level (see also Voss 2005).

These observations also encourage us to examine more closely what we mean by the colonial state and its apparatuses: how these manifested and were experienced or manipulated in different contexts by different actors (cf. M. Hall 2000; Voss 2008). In settler colonial situations such as South Africa, there existed a plurality of colonialisms Christianisation, cadastralisation, forced labour and migration, tribalisation, Indigenous colonialisms - that were felt profoundly but whose infrastructures were unevenly distributed (Landau 2010; Braun 2015). In places, trade networks and settlement penetrated to a limited degree, such that the material record does not disclose the entry of new objects into circulation. This forces us to interpret responses to these colonialisms through the reconfiguration or redeployment of objects and behaviours situated in the longer past. We are prompted to ask how to discern the tipping point where quotidian behaviours begin to acknowledge colonial orders and upheavals. Without a clear 'Before and After' picture, achieving this view becomes a challenging exercise in finding patterns in the longue durée 
using multiple strands of evidence without resorting to essentialisation, or reliance on a hard-and-fast baseline against which to measure change.

Here, I am interested in nuancing the archaeology of colonialisms to allow space for the multi-faceted, often clumsy, piecemeal, and confused nature of state expansion and experiences thereof. Particularly in settler colonies, violence and aggression paralleled exercises in bureaucracy and banality (Stoler \& Cooper 1997). The imposition of settler authority did not proceed apace in all places: outside of major settlements the impacts of European presence could be felt potently, but sometimes more as ripples than as waves. The above-mentioned lexicon is teeming with tools for addressing aspects of these concerns, and so new vocabulary should not be proposed lightly. However, many of these tools still leave me feeling dissatisfied: dissatisfied with their abilities to account for how the misunderstandings and creative re-configurations that accompanied encounters between people and objects related to the unwieldy advance of colonial frontiers; and how places and people that remained largely outside the networks that brought new commodities to the frontier may have imagined themselves as part of other, subtler changes.

In what follows, I want to offer anxiety as a framework for thinking about some of these questions, focusing on south-eastern Africa, particularly the Maloti-Drakensberg Mountains and what would become the British protectorate of Basutoland in 1871, and the independent country of Lesotho in 1966 (Figure 1). To explore the potentials for an anxiety framework, I examine one longstanding archaeological trope of responses to colonialism in southern Africa, namely the twinned ideas of refuge and distress. Amidst the upheavals of the eighteenth and nineteenth centuries, the southern African interior saw an efflorescence of behaviours and settlements often construed as refugia from conflict caused by British governments, Afrikaans-speaking Boer settlers, mixed-race pastoralist-raiders, and internecine aggressions among African chiefdoms. I use the Maloti-Drakensberg situation to interrogate ideas about what constitutes stress and shelter therefrom. These questions imply an interconnection between landscape and stress or, I suggest, anxiety: refugia are places characterised by environmental and physical features as much as by strategy. Thus, my exploration involves re-visiting the Maloti-Drakensberg landscape and its capacity to inspire and challenge certain encounters and lifeways; James Scott's (2009) concept of 'friction' serves as my point of departure. Through a narrative told with historical and archaeological materials (adduced through a similarly hybrid investigative strategy), I explore how anxious encounters related to material practices - including the construction of refugia for colonised and colonisers - and the interpretations or misinterpretations of those practices.

It is worth noting that 'anxiety' features heavily in a different series of discussions related to archaeologies of emotion, elaborated upon in a recent edited volume by Jeffrey Fleisher and Neil Norman (2015) and presaged by Sarah Tarlow (2012). Fleisher and Norman's collection addresses both why and how archaeologists should 'take emotions seriously', especially worry and anxiety in the past. Their introduction and essays within the volume deal with topics such as risk, the 'sensuousness of the state', and archaeologies of 'stressful times'. These are all fascinating and welcome additions to a burgeoning body of literature, and relate to many themes discussed in this essay. The major difference between their conception of anxiety and the framework I outline here is that I do not treat anxiety primarily as an emotion, but rather as something closer to an epistemology (following Stoler 2009): a set of habits of thinking about and within the world that can manifest themselves in 
affect and behaviour. The degree of difference between these two definitions of anxiety is perhaps small and worth further exploration in a different venue (King forthcoming c). My hope here is that this essay will contribute to what is appearing as a stimulating archaeological field of enquiry.

\section{Tensions and topographies}

The thrust of the theoretical position advanced here is twofold: anxiety describes a state of being derived from the tension between peoples' experiences, visions for the future, and uncertainties stemming from epistemic encounters with new people, objects, and behaviours; friction describes how the landscape can limit the intrusion of colonial authority and thereby affects how that authority is encountered.

\subsection{Anxiety and uncertain encounters}

Anxiety is most commonly thought of - when it is thought of at all - as an emotion. Put another way, anxiety has come to represent an introspective experience, a preoccupation with a 'unique self' accessible through psychotherapeutic confession (Freud 1952; Bourke $2003,129)$. However, Freud's original formulation of anxiety was concerned with the tensions between the self and the instabilities or uncertainties of modernity. Freud (1930, 63) was particularly concerned with anxiety as it related to the sublimation of human instinct as a response to the evolution of civilisation and modern society. In articulating this, he was concerned to distinguish anxiety from fear: fear was more immediate and focused on a distinct object, while anxiety lacked a specific object and instead directed attention to the condition itself (Freud 1952, 103). Rationality and irrationality were not part of the equation; the distinguishing characteristic between the two states was the degree to which a person or persons believed themselves capable of coping with uncertainty and/or danger. Existential philosophers, including Kierkegaard, Nietzsche, and Heidegger further emphasised the creative potential inhering in anxiety, as anxiety prompted people to recognise the instability of meaning and thus become more 'real' (cf. Jackson \& Everts 2010).

Work by anthropologists such as Bronislaw Malinowski and - most significantly here - Mary Douglas was foundational in bringing anxiety into contemporary social anthropology via structuralist frameworks. In Purity and Danger (1966), Douglas famously defined anxiety as relating to 'matter out of place': anxiety described the consequences (symbolic, material, practical) that occur when the classificatory systems that people use to comprehend society and the world are transgressed. This sort of anxiety was unavoidable, as it was impossible to have such a classificatory system (and all societies do) without also having aberrations from that system: 'where there is dirt there is a system', and vice versa (Douglas 1966, 35). Anxiety both allows people to identify these aberrations and instabilities, and to find recourse to the mechanisms necessary for righting the system. In invoking these corrective measures, however, anxiety also entails discerning whether transgressive anomalies are limited to an individual's experience or indicators of a larger social problem. If the latter, the anomaly takes on the status 'danger', and thus demands collective action against it (Douglas 1966, 149-51). Here, it is important to underscore one specific feature of Douglas's work: that anxiety relates to the process of making sense of the world as an epistemological practice.

Ann Laura Stoler $(2008,2009)$ offers a means of relating these sorts of 'epistemic anxieties' to the practices and power dynamics at work in the colonial state - in particular the settler 
colonial state with its patchily distributed authority. Stoler's work examines how colonial ways of thinking about race were developed, enacted in policy, and sometimes concealed within the Netherlands East Indies. This project constituted epistemic work, and in carrying it out colonial agents relied on their sensibilities and assumptions more than on scientific or dependable observations. Epistemologies were 'what people did' (Stoler 2008, 351), and this unstable information became the basis for predicting subversion and revolt among colonial subjects. Stoler's conclusions apply beyond the government office: this sort of 'making sense' or 'making up' of people was an everyday part of the colonial milieu. These epistemologies were embodied anxieties - they exerted an invisible force that guided how people experienced colonial encounters and moved through the world, animating and nuancing the practical resources they employed to cope with this uncertainty.

If the power dynamics here are not underlined clearly enough, Joanna Bourke's $(2003,127)$ historical study of anxiety and fear clarifies that power resides in the options available for managing these uncertainties. The Dutch officials described in Stoler's study could address their racial anxieties by legislating, moving, or spatially constraining colonised bodies and practices. Colonial subjects were not without resources of their own - the modes of resistance and responses to entanglement described above - but they were of a different nature than the colonisers' and lacking the same force of apparatus.

With respect to the ways in which these actions have been treated in the archaeological literature on culture contact, of particular significance here is the distinction that Andrew Martindale - drawing on the work of Anthony Giddens, Ann Stahl, and Michael Dietler - has drawn between discursive and non-discursive experiences of power. Martindale $(2009,64)$ describes the former as 'intentional actions' deliberately addressing colonial impositions, and the latter as 'symbolic gestures of aesthetics, taste, and appropriateness' that emphasise the more casual, less deliberate use of objects circulating in a colonial milieu. Discursive and non-discursive opportunities were both available in situations of culturecontact. Of significance for my argument is that both Martindale and Stahl (2002) emphasise that we should understand actors in colonial situations as being aware of their historical position; that is, discursive and non-discursive practices draw on peoples' empirical experiences and concerns about the future.

Enter anxiety, as a way of tying this historical awareness and future concerns with the uncertainty of epistemic encounters, and how these are embodied in the resources people brought to bear on making sense of these encounters.

\subsection{Frictional landscapes}

Landscapes can be both resources and actors here. James Scott's (2009) work on landscape friction offers a means of relating the uncertainties of colonial experiences to the character of certain kinds of landscape. Writing of southeast Asian communities wishing to remain independent of government control, Scott emphasises that mountains present a means for local people to negotiate their identities in the face of state authorities. He locates the transborder region of 'Zomia' (a neologism describing a borderless 'ungovernable' zone) within a global historical trend of peoples resisting the cultural and economic standardisation accompanying colonialism (Braudel 1995, 34; Gellner 1969); rejecting sedentary agriculture, moving to the mountainous periphery, adopting nomadism and raiding, all with a pronounced degree of cultural heterogeneity (Scott 2009, x, 12, 22). 
Scott proposes 'friction' as the topographical and environmental constraints that a landscape places on the intrusion of state, political, economic, and cultural influences. For my purposes, it is significant that in Scott's formulation mountains (and their inhabitants) impede not only the large-scale settlement of colonial and agriculturist states, but also the more piecemeal establishment of infrastructure such as roads and trading posts. Mountains present rugged, broken terrain often at great distances from centres of governance, which inhibits or prevents centralising efforts such as large-scale crop cultivation, transport systems, and communication. ${ }^{1}$

By introducing friction into his larger study on 'the art of not being governed', Scott emphasises how friction limits the degree to which people can be co-opted into state systems, and the force that the state can exert to compel such participation. I wish to focus instead on how friction shapes the nature of encounters that occurred in the context of colonial expansion. These encounters initially took the form of forays made by administrators and colonial representatives tasked with specific aims. As the MalotiDrakensberg came to be associated with escape for cattle thieves and sanctuary for the last independent Bushmen, the tone shifted to one of exploration and law enforcement, despite the overwhelming inability of Europeans to achieve this second directive. This historical context is elaborated upon below.

\section{Refugia on southern African frontiers}

I want to proceed by examining considerations of refugia as reactions to colonial expansion and internal socio-political turmoil in southern Africa. This has been a persistent theme in archaeologies of the last 500 years, with 'refuge' being used both in its Latin sense of 'hideaway' and in its anthropological sense connoting habitable pockets or reservoirs amidst increasingly harsh socio-environmental conditions. In reviewing this literature, I seek to draw out a series of inferences about why people take refuge. Describing something as a refuge requires that we think carefully about what it is a refuge from. Earlier studies have dealt mainly in terms of stress, either ambient or as a direct threat. In some instances refuge was a reaction to imminent violence, a redoubt from which to defend against immediate harm. Refuge has also been interpreted as a response to more amorphous changes in political, climatic, and socioeconomic orders. The implication is that when such changes occurred, people (sometimes aggregated into homesteads, sometimes into larger communities) removed themselves to strategic, defensive, and temporary locations to await the abatement of these detrimental circumstances. In this, refugia constituted relief: these people did not survive or recover just because they moved, but because they moved to places that were inaccessible to or protected from whomever or whatever was perceived as the aggressor. Put another way, refugia appeared as a response to particular stressors, some of which conform to the ideas of anxiety as an experience of 'making sense' that I elaborate upon below.

The latter half of the second millennium AD witnessed large-scale demographic change, internal political crisis, and violence in the interior Highveld (Figure 2) - changes that lack a single cause but rather speak to chain reactions implicating the rise of ambitious African leaders and, eventually, the expansion of British and Afrikaner settlement (Etherington 2001; S. Hall 2012; Landau 2010; see also papers in Hamilton 1995). Beginning perhaps as early as the seventeenth or eighteenth centuries (Parsons 1995) but coming more sharply into (historical) focus from the late eighteenth century, this period is characterised by the 
consolidation of numerous Highveld chieftaincies, competition for cattle and followers, and raids for cattle and captives by Griqua and Korana pastoralists. The early nineteenth century saw intense fission and re-alignments among chieftaincies and widespread population relocation as new chiefly centres were established. This period from the early to midnineteenth century is often referred to as the lifaqane ('time of troubles'), describing the complex political manoeuvers of African chiefs and their cascading consequences, including massive population movements and a (supposed) uptick in cattle raiding (King forthcoming b). Throughout the lifaqane and the rest of the nineteenth century, British and Afrikaner settlement steadily expanding into the interior accompanied the penetration of trade networks, land speculation, mineral extraction, and violent confrontations with African chiefs and hunter-pastoralists. Practically, the lifaqane and its long 'prelude' were felt through ever-intensifying cattle raids that diminished or depleted perhaps the single most powerful form of political currency available (ibid.). ${ }^{2}$

The efflorescence of settlements located atop steep-sided, easily defensible kopjes within the last 500 years has been attributed to people seeking a reprieve from this prolonged period of demographic unrest and spates of violent raiding. In the Waterberg region, large population influxes (perhaps from the south-east, see competing theories in Maggs 1976, 142 and Huffman 2004, 2007) during the seventeenth century may have provoked already established residents to retreat to easily fortified positions (Huffman 1990; S. Hall 1995, 30910). At fortress-type sites such as Rooikrans (S. Hall 1985), the use of space emphasised expediency, with small stock enclosures and food and bone waste showing a very small quantity of livestock remains, in contrast to more robust contemporary settlements such as Rhenosterkloof.

Other sites from the seventeenth and eighteenth centuries such as Malore Hill (Huffman 2004, 93) and Moor Park (P. Mitchell \& Whitelaw 2005, 227; Whitelaw 2008, 2009, 2015) are similarly characterised by positions on fairly inaccessible rises, defensive walling, and expedient or temporary construction. Huffman $(2004,89)$ and Whitelaw $(2009)$ have suggested that, particularly in the south-eastern subcontinent where Moor Park is located, constructing these sorts of sites may initially have been a response to the effects of the Little Ice Age, which caused a decline in agricultural productivity and spurred tensions among agropastoralists. The consequences of these tensions may have been an increase in cattle raiding, which motivated people to re-locate to more strategic and defensible locations. In combination with the political re-alignments occurring within this region's emergent polities (M. Hall 1981; M. Hall and Mack 1983; M. Hall and Maggs 1979; Whitelaw 2008), Moor Park appears as a refuge site disclosing concern over security in food, livestock, and people.

Moving into the early nineteenth century, the site of Lepalong cave (occupied c. 1827) shows archaeological indicators of social stress directly attributable to the onset of the lifaqane. These include a number of small animal enclosures and the lack of a coherent settlement layout, perhaps reflecting the deterioration of socially unifying architectural patterns and homestead constructions (S. Hall 1995, 314-9; cf. Whitelaw 2013, 219-21).

Significantly, these instances of refugia are not attributed directly to colonial intrusions, but rather to internal turmoil among African polities eventually exacerbated by the actions of the colony and its agents elsewhere in the subcontinent.

These refugia stand in stark contrast to the Great Places or agglomerated towns that defined settled chieftaincies in southern Africa during the eighteenth and nineteenth centuries. 
Unlike Rooikrans and Rhenosterkloof, late eighteenth-/early nineteenth-century Tswana agglomerated towns in the western Highveld disclose the rise of a handful of dominant chieftaincies that supported elaborate spatial planning, architectural styles, and diverse ceramic assemblages. Large populations deployed a range of ceramic, metallurgical, and building technologies to address the boundaries between family and community through time (S. Hall 1998, 2012; S. Hall et al. 2008). Farther to the south-east amidst the ascendant Zulu chiefdom, early to mid-nineteenth-century chiefly centres such as Mgungundlovu and oNdini contain extensive deposits attesting to large quantities of goods such as cattle and grain arriving from tributaries (Parkington \& Cronin 1979, Plug \& Roodt 1990). Settlement layouts describe the organisation of Zulu society into strictly demarcated spaces based on social status and age-set (Watson \& Watson 1990). While they have yet to be excavated, the Great Places of Xhosa chiefs at the Cape dating to the same period appear - through historical sources - to have displayed similar spatial elaboration (Peires 1981).

Gavin Whitelaw and Simon Hall (2016) have re-visited features of the lifaqane as part of a broader, long-term series of frontier dynamics rather than as primarily reflecting distress. They draw on archaeological and oral historical evidence to build a view of the interior as overlapping 'layered landscapes'. Utilising Kopytoff's (1987) 'internal African frontier' model, Whitelaw and Hall illustrate how, for the past four or five centuries, successive interactions of populations moving through the interior have resulted in identities accreting and being expressed in material cultures such as ceramic production and architecture. In this interpretation, population movement was commonplace. Despite producing extensive stone-walled settlements, communities in the interior relocated en masse on a relatively frequent basis (at least once within a generation), with no indication that such migration was a reaction to crisis or stress. This prompts a re-consideration of the refuge sites described above: if population movement was relatively common, might these apparently expedient sites reference some aspect of this pattern rather than a break with 'normal', sedentary lifeways?

This is not to say that we cannot confidently describe some archaeological sites as 'refugia' from more readily discernible causes, sometimes articulating fear of a specific, direct threat. Amanda Esterhuysen's (2006, 2012) study of Historic Cave describes the 1854 siege of the Kekana Ndebele chief Mugombane. Boer forces besieged Mugombane, with his family and follwers, in the cave for a month before entering, killing the men, and 'dispersing' the women and children among Boers. Archaeologically, the result is a wealth of material culture, including mummified individuals and flora and fauna suggesting calculated provisioning strategies that kept certain high-status individuals nourished the expense of others. The 1879 siege of the BaPhuthi chief Moorosi and his rebels by British forces and BaSotho auxiliaries is another similar example. Moorosi's story is described in greater detail below, but his fortified mountain Thaba Moorosi ('Mount Moorosi') was besieged for eight months before it fell to an invading force armed with ladders, cannon, and guns.

In these cases, refugia were responses to a particular set of stressors, some amorphous and some desperately clear. In what follows, I want to focus in greater detail on how to conceive of refuge in the context of anxieties, especially anxieties that referenced particular uncertainties about 'making sense' of people and landscape. In the Maloti-Drakensberg, it becomes apparent that refugia were one of many material (and archaeological) ways of negotiating anxieties, and that refugia were resources accessed in different forms by both colonisers and colonised. 


\section{Friction at work in the Maloti-Drakensberg}

Historians and archaeologists have long characterised the Maloti-Drakensberg Mountains as refugia. John Wright (1971) and Patricia Vinnicombe (2009) described the region as a stronghold of Bushman raiders escaping colonial encroachment. Peter Mitchell (2009a, b) has drawn attention to these mountains as the last best option for Bushmen ${ }^{3}$ wishing to lead independent lifeways in the face of growing European and Bantu-speaker settlement. In this, Mitchell - along with several historians - voices the position of refugia as relief: the MalotiDrakensberg offered a sanctuary for mobile hunter-gatherers because the landscape challenged the encroachment of farming lifeways and state infrastructure.

These depictions of landscape drew on its rugged topographic and climatic aspects. The Maloti-Drakensberg are southern Africa's highest mountains (Figure 3), rising 3,482 metres above sea level at their maximum and creating a profound rain shadow effect to the west. Salient features of the region include: extreme temperature variation (over $30^{\circ} \mathrm{C}$ in the summer and below freezing in the winter); heavily dissected and eroded terrain; vegetal zones transitioning from palatable grasslands to unpalatable alpine veld; and an abundance of microclimates at varying elevations (Mucina et al. 2006, 390; Rutherford et al. 2011, 44-5, 48; Showers 2005). The landscape further consists of a tremendous number of steep-sided kopjes (liqhobosheane in Sesotho) that mirror the defensive hilltop positions described by Huffman, Hall, and others to the north; I return to these in the following section.

Given this portrait, it is perhaps unsurprising that archaeological evidence suggests that agriculturists only settled in the highlands in the late nineteenth century, as part of a political strategy by the BaSotho royal house (King et al. 2014, 59-60; Leselinyana 1909; Mitchell \& Whitelaw 2005, 232-3; Thorp 2000). These areas were attractive primarily to those leading hunter-gatherer lifeways, which had persisted for millennia and from c. 1,800 BP speak to contact with agropastoralists (Mitchell 2009a, b). These lifeways continued even after colonial settlement and administrative oversight encroached around the base of the mountains. This encroachment constricted hunter-gatherers' range of movement and hunting opportunities, and prompted many to see stock theft as both economic recourse and political resistance (Challis 2008, 2012; Mitchell 2010; Mitchell \& Challis 2008; Vinnicombe 2009; Wright 1971).

The Maloti-Drakensberg thus presented difficulties for peoples wishing to practice sedentary agriculture or, after the western Maloti-Drakensberg's 1871 annexation to the Cape as Basutoland, establish centres of government administration (Figure 4). In 1869, the British official James Bowker undertook an exploratory trek from the southern Drakensberg over the Escarpment and down the Senqu River. His notes from the journey include phrases such as: 'with reference to the story of available ground, it is all a mistake'; 'there is not one acre of ground fit for anything but a baboon or a Bushman'; 'we were often for a whole day without even a footpath' (Theal, V, 126-8). Four years later, James Murray Grant of the Frontier Armed Mounted Police observed that the far-upland region was almost devoid of settlement except for the lone trading post at a lower-lying mountain pass (Mitchell \& Challis 2008). The upper reaches of the Maloti-Drakensberg were deemed untameable, inaccessible, and generally beyond the reach of British government and its infrastructure (Ayliff 1879). Consequently, magistracies - the main apparatus for administering Britian's system of indirect rule - as well as post offices and all but a few traders joined the longer tradition of mission stations being concentrated in the lowlands. 
Recalling Scott's formulation, the Maloti-Drakensberg was a frictional landscape. As such, it became a locus of anxiety: its unknowability and untameability frustrated and worried those wishing to bring order to the region; that same unknowability afforded opportunities for those wishing to observe and avoid such authority. Here we see one association between refugia and anxiety: one man's refuge is another man's 'nest of thieves' (Theal, V, 209). While the highlands made an unfavourable impression on Bowker, Grant, and others (King 2015), the region's topographic and microlimatic variation generated a mosaic of environments that proved attractive for people undertaking mobile lifeways (Mitchell 2009a). Indeed, in the nineteenth century, the inaccessible upper reaches of the mountains became a hub for communities of raiders who stole cattle, guns, and horses from one another and from colonists. Detailed below, here it is worth noting that these practices were so widespread and cohesive that Rachel King and Sam Challis (forthcoming) have referred to the Maloti-Drakensberg as an 'interior world' (pace Zappia 2014) in which such 'outlaw' activities were the norm rather than the exception.

Magistracies, police stations, and mission stations at the edges of the mountains served colonists as refugia in their own right, as nodes of control and intelligibility that helped manage anxiety over the friction of the mountains. Viewed from the 'interior world' of the Maloti-Drakensberg, these institutions were the source of another sort of anxiety, about the intent, movement, and potential for violence that colonists represented. The following section explores this in greater detail, with emphasis on the recursive relationship between refuge and anxiety.

\section{Close encounters of the cattle-raiding kind}

The Maloti-Drakensberg thus appears as a landscape characterised by refugia. Physically, this is clear with respect to the many liqhobosheane that contain evidence of settlement for varying durations and which - following the above-described linkage between stress and defensive settlement - may initially appear as temporary shelters. However, I want to illustrate here, both through historical narrative and the archaeological record, that refuge and anxiety were not linked in a strictly causative sense: refuge was not simply a defensive posture responding to stressors. Refugia fit into broader processes, practices, and habits of 'making sense' on this frontier. Further, refugia were not just resources of Africans but also of Europeans, albeit in different forms but still acting as places that embodied certain anxieties to do with - in this case - theft and rebellion.

Investigating these aspects of the Maloti-Drakensberg demands a hybrid archaeological, historical, and ethnographic approach sensitive to the contingencies that shaped decisions about settlement, mobility, and landscape use. ${ }^{4}$ It is also necessary to account for the fact that owing to the heavily eroded nature of the region, the sustained impacts of homesteadbuilding, farming, and grazing has made preserved open air sites a rarity (Mitchell 2013). A systematic survey of $20 \mathrm{~km}^{2}$ was launched as an exploratory exercise to ascertain whether and how accurately ephemeral or deflated sites could be detected in an area of the southern Maloti-Drakensberg with relatively favourable preservation conditions. The survey revealed 62 sites (Figure 5), including occupation on hillslopes that reflected small-scale terracing and household 'keyhole' gardens. On hilltops themselves, the survey detected deflated middens associated with the remains of a series of structures identified (based on the presence/absence of dwelling platforms) as storage and dwellings. Middens yielded samples of decorated and undecorated ceramics, including examples of manufacturing and 
decorative traditions characteristic of the southern Highveld from the eighteenth and nineteenth centuries (Huffman 2007, 179-81). However, perhaps one of the most striking features of these sites is their distance from a water source, although the potential to harvest rainwater from the numerous naturally-occurring cupules in the sandstone should not be discounted. This feature alone puts one in mind of temporary shelter: whether such places served as a relief or redoubt, they initially appear consistent with the model developed farther to the north connoting a means of coping with stress.

Historical considerations suggest other interpretations, however, and encourage us to consider the many ways that anxiety may have been experienced. As there were no comparative 'micro-historical' studies of the southern Maloti-Drakensberg's recent past prior to this research, new archival and ethnographic work proceeded alongside archaeological investigations, and made it possible to tack between these three strands of evidence (cf. Stahl 2001).

The picture that emerged was one of varying interpretations of chieftaincy, settlement, and landscape use, illegal or illicit economies (cf. Hartnett \& Dawdy 2013), and anxieties attendant thereupon. From roughly 1820 the area south of the Senqu River was under the authority of a chiefdom known as BaPhuthi, under the successive leadership of chiefs Mokuoane and Moorosi. BaPhuthi served as tributaries of the BaSotho leader Moshoeshoe I in the area bounded by the Senqu, Escarpment, Stormberg, and Wittebergen Mountain ranges. However, Mokuoane, Moorosi, and their polity functioned relatively autonomously. By the 1820s, BaPhuthi had built considerable reputations as cattle raiders throughout the southern Maloti-Drakensberg. Raiding cattle was a common practice among southern Bantuspeaking chiefdoms, and was a way for men to demonstrate leadership, skill in riding and combat, and to obtain cattle with which to make marriage and political alliances (King forthcoming b).

Mokuoane and Moorosi appear to have treated cattle raiding - of both European farmers and other chiefdoms - as an artform (cf. Morton 2009). They rejected the idea of a chiefly Great Place as described above, instead developing a peripatetic form of chieftainship that involved circulating through a series of settlements on liqhobosheane scattered along the Senqu. The reasons for these movements seem to have been diverse - finding a strategic location for raiding cattle, attending to political matters - and involved anywhere from a handful of raiders to the entire polity. Careful reading of archives made it possible to identify these settlements (Figure 6), whose locations facilitated both stock acquisition across a wider area and also opportunities for concealment and misdirection should victims of stock theft seek retribution (King 2014, 129-31; cf. Theal, I, 153). Subsistence appears to have emphasised garden agriculture rather than field cultivation, which facilitated BaPhuthi mobility and meant that movements were unconstrained by the seasonal schedule of largerscale crop agriculture.

Mokuoane's and Moorosi's peripatetic strategy helped keep the boundaries of their chiefdom flexible, which highlights one aspect of anxiety: the process of managing uncertainty surrounding the changing activities and desires of British authorities. This was particularly intense because conflicts between Moshoeshoe's BaSotho and Boers in the Orange Free State Republic (Figure 2) along with British expansion into the interior meant that the borders of Moshoeshoe's (and by extension Moorosi's) territories were in a nearconstant state of flux. While maintaining their string of settlements at the heart of their chiefdom, BaPhuthi could adjust their movements as needed to affect raids, retreat 
therefrom, and avoid retribution. In doing so they took advantage of the landscape's friction, which limited opportunities for pursuit and surveillance, especially by colonial officials and militia (King 2014, 145-7); about this, further below.

This is an especially necessary and significant feature because of the widespread nature of raiding and, by extension, the intensifying efforts to punish it. A vast body of scholarship in the last four decades has detailed the phenomenon of 'Bushman raiding' throughout the mountains. As mentioned above, these raiders were initially described as ethnic San fighting for a dying way of life (Vinnicombe 2009; Wright 1971). However, rock art studies by Geoff Blundell (2004), Lara Mallen (2008), and Challis (2008; 2012; 2016) have revealed that these raiding bands were in fact culturally heterogeneous mixtures of Bantu-speakers, Bushmen, and former slaves. These raiders operated throughout the Maloti-Drakensberg and on both sides of the Escarpment, tracing many of the same routes as BaPhuthi - and often raiding alongside them and other chiefdoms (King \& Challis forthcoming).

British authorities were so acutely aware of the attractiveness of both the BaPhuthi chiefdom and the landscape (especially given the latter's fluctuating borders) for raiders that Basutoland Governor's Agent James Bowker wrote of how the lands south of the Senqu would 'if not arranged in some way, become a nest for thieves and vagrants from all the adjoining tribes' (Theal, $V, 208$ ). This was not just fear and foreboding of events in the distant future, but anxiety stemming from observations of groups of Thembu coming from the south-east to settle in Moorosi's lands; of militia from Natal encountering raiders and stolen cattle in the upper reaches of the Senqu; and of fears that from 1859 Moorosi had consolidated his followers in the highlands and 'let loose his thieves upon the [Tele River] border, and [...] taken to himself the position of the head of a Banditti of robbers' (Theal, IV, 449). Anxiety about a mass southern African uprising was widespread, and a singular preoccupation of many officials was to ascertain the plans and inner workings of certain chiefdoms, and determine if these posed a threat (Eldredge 2007, 48-9; Etherington 2004, 207).

The concern to 'arrange' the southern Maloti-Drakensberg brings us to colonial anxieties about BaPhuthi and the mountains. British attempts to mitigate and respond to these fears were expressed both through retaliation by militia, and also the creation of institutions such as gaols, magistracies, police stations, and 'native reserves' to control raiders and potential raiders. Such institutions served (as has been discussed elsewhere, Bradford 2000; Braun 2015) as extensions of colonial power and, equally significantly, as refugia for colonial authorities. The 1850 establishment of the Wittebergen Native Reserve effectively closed off the western end of Moorosi's raiding ambit. The Reserve further implemented a twinned programme of Christianisation (administered through the Wesleyan mission station housed there) and subsidised agriculture to produce a class of peasant labourers, thus discouraging people from joining raiding bands to make a profit (Bundy 1987; King forthcoming a). Moorosi was expelled from the Reserve in 1859 to safeguard the Reserve's mission and inhabitants (Theal, III, 106). The establishment of magistracies equipped with gaols within Moorosi's territories from 1877 were efforts to monitor and constrain BaPhuthi activity while affording magistrates a measure of security and the physical, symbolic support of the colony's infrastructure. In 1878, when the magistrate deemed his lodgings in Basutoland unsafe in the face of what he saw as mounting rebellion among BaPhuthi, he retreated with his family to the police station across the Tele (Eldredge 2007, 57-9). While the magistrate maintained that he did so out of an immediate and credible fear for his life (Austen 1879, 
1880), his actions serve as a useful illustration that gaols and the trappings of the law were no longer deemed sufficient means of addressing his anxiety over Moorosi's chiefdom; only an armed military force would do.

Moorosi and his BaPhuthi observed the construction of these elements of colonial control and refuge with their own anxieties; changes in raiding patterns and occupation of BaPhuthi liqhobosheane disclose how these were experienced. When the Reserve curtailed BaPhuthi raids at the western end of Moorosi's ambit, BaPhuthi shifted from Lefika la bo Khiba to Bolepeletsa and re-oriented their raiding focus to the south and east (Wright 1971, 170). As Basutoland's borders were codified between 1868-71, and the magistracy at Quthing established next to Bolepeletsa in 1877, BaPhuthi raiding attentions shifted yet again. Concentrating more heavily on Natal and eastern Nomansland, BaPhuthi increasingly relied upon rockshelters and settlements higher into the mountains around the Tsoelike and upper Senqu Rivers for sheltering people and livestock (King 2014, 183-4; Mitchell 2010).

While Moorosi's liqhobosheane were places that kept colonial authorities at arm's length during these reconfigurations, it would be a mistake to assume that they were a form of refuge implying disconnection from the rest of the frontier. Excavations at the base of Bolepeletsa demonstrate that despite the increased surveillance and concomitant modifications of BaPhuthi movements in the $1860 \mathrm{~s}$ and $70 \mathrm{~s}$, manufactured goods (nails, tacks, beads) continued to make their way onto or around Bolepeletsa. Disruptions to trade, the consumption and production of goods, and other ways of life could and very likely did happen as a result of BaPhuthi institutionalised cattle raiding and reprisals from farmers and government officials; but they did not manifest themselves in a restriction of goods available through virtually all regional traders.

Indeed, there appears to have been a delicate balance between remaining far enough from the events, laws, apparatuses, and activities of colonists on the frontier, and staying close enough to 'make sense' of the people, motivations, and events there. Particularly once magistrates arrived in Basutoland, Moorosi spent a great deal of time and energy exploring how he could provoke, enrage, impress, and placate them (Eldredge 2007). He did the same with his missionary, D.F. Ellenberger (1879).

From the perspective of British officials and missionaries, it becomes apparent that many of their anxieties concerned efforts to 'make sense' of Moorosi and his chiefdom: could they be compelled to adopt agriculture, as other southern African chiefs had (Beinart 1982;

Stapleton 2001; Thompson 1975)? Was their mobility a permanent condition as with Bushmen or could they be induced to become sedentary? Could they be treated with as Moshoeshoe was or were they more a consortium of rogues than a chieftaincy?

In 1844, the French missionary Christian Schrumpf established the Bethesda station among BaPhuthi at their Maphutšeng settlement, in the hope of bringing Christianity and sedentary agriculture to Moorosi's people. Schrumpf was shocked and appalled when, only a year later, Moorosi announced that his people would move to another settlement at Maphutšeng. Schrumpf (1847) and his brethren raged that Moorosi did not understand the purpose of a mission station, while such sedentism was not compatible with (or desirable for) BaPhuthi lifeways. Later, at the Wittebergen Reserve, superintendent John Austen sought to curtail BaPhuthi mobility in the Reserve (which Austen perceived as a threat) by closing off roads they were known to have used (Theal, IV, 271). The mobilisation of Frontier Armed Mounted Police stations near the Tele River and in between the Reserve and 
Moorosi's settlements at Bolepeletsa partly aimed at providing additional surveillance and policing of raiders (Griffith 1879; Mitchell \& Challis 2008). Similarly, the establishment of magistracies within Moorosi's territories were efforts to monitor BaPhuthi activities. New magisterial powers were aimed at parsing and enervating Moorosi's chieftaincy by undermining his abilities to, for example, allocate land for grazing and settlement and fine people for selling beer without his permission (Eldredge 2007, 42-6).

What becomes clear in this discussion is how BaPhuthi and colonial authorities attempted to 'make sense' of one another, and how their material gestures and movements through the landscape were part of this process. BaPhuthi raiding and settlement strategies were part of an understanding of colonial surveillance, control, political demarcation - and sometimes refuge from these. Colonial strategies of policing and the infrastructure that these entailed changed based on the unknowability of the terrain, and assumptions or beliefs about how BaPhuthi (and Moorosi in particular) were behaving. These were fundamentally anxious encounters, with all parties drawing on their sensibilities and experiences to manage uncertainty surrounding their security in a landscape characterised by friction and political flux.

\section{Conclusion}

At the heart of this essay lies the questions, does exploring the natures and manifestations of anxieties over time change our perspective on what constitutes refuge, especially in a colonial context? And in light of these many anxieties, is it still useful to think in terms of refuge and stress? To summarise and drive home the value of this perspectival shift, it is worth re-visiting Moorosi's 1879 rebellion mentioned above and contextualised in the preceding section. Whether one views the siege of his mountain holdfast from an archaeological or historical perspective, it is unquestionably a refuge in the face of a direct, immediate, and sometimes terrifying threat; one British soldier eventually took to lining up the skulls of dead rebels atop the barricades 'as a warning to the [Africans]' (Start 1879). However, the use of landscape to keep colonial forces at bay (at least temporarily) was not, as we have seen, a radical departure from longstanding BaPhuthi practices. Although the mountain proved to be a last redoubt, the strategies Moorosi used to provision it (drawing upon cattle kept with allies in the highlands) and harry troops (sending auxiliary forces to liqhobosheane around the area) were in keeping with longer-term understandings of the landscape and of the men and institutions attempting to control it (King 2014, 204-6).

Speaking of refuge demands that we ask, 'refuge from what?', and interrogate the nature of the stressors that refuge implicates: why do we believe these to be stressors? What is the basis for assuming how people experienced and perceived these stressors? These are questions we can ask of the pre-colonial past as well as the colonial, especially as recent work on the southern African Iron Age has explored how settlement and mobility were significant constituents of social identity (Ashley et al. 2016).

For the present, it is worth referring back to Dawdy's caution at the beginning of this paper, that we be careful lest we endow the march of the colonial frontier with too much presence and too much power. While contests among African chiefdoms and the encroachment of settler colonists into the interior undoubtedly had profound impacts on peoples' lives, these were not felt the same in all places. The story of the southern Maloti-Drakensberg illustrates that the use of easily defensible, water-scarce liqhobosheane was not so pernicious or calamitous a response to the frontier as some uses of 'refuge' would suggest, but part of a 
more complex and sustained series of engagements. BaPhuthi and other raiders were capable of 'making sense' of, contesting, and shaping mechanisms of colonial expansion processes manifested through the use of liqhobosheane (King \& Challis forthcoming). Similarly, officials charged with 'arranging' BaPhuthi territories and activities were preoccupied with their own sense-making endeavours and efforts to translate these into programmes of security and control. Some of these projects achieved their aims, some didn't.

What I have foregrounded here is how anxiety - encompassing both uncertainty and how it is managed - affords opportunities for expressing human agency, desire, and understanding. Anxiety's emphasis on empirical experiences and concerns about the future allow us to see how institutions such as peripatetic settlement, use of liqhobosheane, and cattle raiding inform and inflect engagements with colonial projects. Inasmuch as settler colonialism was characterised by processes of transformation perhaps more than conquest (Stoler \& Cooper 1997), that transformation betrays apprehensions and misapprehensions of land and people, which in turn directs our attention to the state's failures as much as its successes.

This approach lends itself to other settler colonial contexts, both within southern Africa (e.g. the Middle Orange River and northern Cape frontier, Legassick 2010; McGranaghan 2016; Penn 2005) and elsewhere such as Australia and North America (Hämäläinen 2008; Hyde 2011; White 1991; Zappia 2014). While critiques of colonialism as shared or entangled milieu have concerned a lack of attention to violent confrontation and exploitation (GonzálezRuibal 2014, 17-8), anxiety creates space to explore the trauma of these situations. Conceiving of colonialism as a series of epistemic encounters invites explorations of how 'making sense' processes have consequences that could be both creative and catastrophic. Anxiety allows us to address the fallibility of the state in the same frame as the very real impacts of its material apparatuses.

It also contributes to the on-going conversation around how to develop historical archaeologies of and in Africa. One of the leading preoccupations of African historical archaeologies has been treatments of modern and pre-modern worlds on the continent (Hall 2000; Reid \& Lane 2004; Schmidt \& Walz 2007; Stahl 2001, 2009). This division has been heavily critiqued as Eurocentric, de-privileging African voices, and over-privileging state power; with good reason. Yet there is still a need to pay attention to how experts, politicians, and publics use the past to narrate and assert a place for Africa in the modern, globalised world. These conversations often fall under the purview of heritage, but 'the politics of the past' have real implications for historical archaeological methodologies. I mean this in a very particular sense: in post-independence and heavily globalised Africa, the 'stuff' of the longue durée and the experiences they disclose have literally become the 'stuff' of which national and cultural identities have been forged and disputed. One need only look as far as the South Africa's \#RhodesMustFall movement to see this in action at a large scale.

However, Andrew Reid (2016) has recently emphasised that the materiality of the past often works in the service of these and other projects at a lower key. Reid refers to this sort of past as 'obvious truisms': nuances of (for instance) landscape and architecture that are laden with memory and power precisely because they are mundane and taken-for-granted rather than monumental. Reid $(2016,202)$ argues that exploring these features offers a window onto 'present day mindsets and psychoses'. An archaeology of anxiety takes such material 'truisms' - like refuge and stress - as its specific focus. Viewing these as the ken of historical archaeology allows us to see how these materials continue to be contested, narrated, and 
negotiated through time, thus defining historical archaeology through the convergence of material, written, and oral perspectives rather than temporal delineations (Lane 2016, 1745). Perhaps, then, it's useful for African historical archaeologists to be a bit anxious.

\section{Notes}

${ }^{1}$ It is worth noting that in the Kalahari - arguably another sort of frictional landscape hunter-gatherer lifeways persisted even after these state apparatuses manifested themselves.

${ }^{2}$ Whether or to what degree we can think of cattle raids as analogs for warfare is a question that has split southern African historians. See King forthcoming $b$.

${ }^{3}$ Debates over the ethnicised content of 'San' and 'Bushmen' defy summary here. Here I use 'Bushman' specifically for eighteenth- and nineteenth-century hunter-raider-pastoralist communities described in the Maloti-Drakensberg and, arguably, in the northern and eastern Cape (McGranaghan 2016).

${ }^{4}$ Details of the survey and excavation data presented here, as well as the research design and methodologies through which they were generated, can be found in King 2014, ch. 7 and 8, Appendices $\mathrm{D}$ and $\mathrm{E}$.

\section{Acknowledgements}

The fieldwork for this research was funded by grants from a Tweedie Exploration Fellowship for Students from the University of Edinburgh and a Clarendon Scholarship from the University of Oxford. This paper was written during my tenure as Smuts Research Fellow in African Studies and with generous support from the Smuts Memorial Fund. I thank Mark McGranaghan, Peter Mitchell, and two reviewers for comments on earlier versions of this paper. 


\section{Figure captions}

Figure 1 Map of southern Africa and Maloti-Drakensberg.

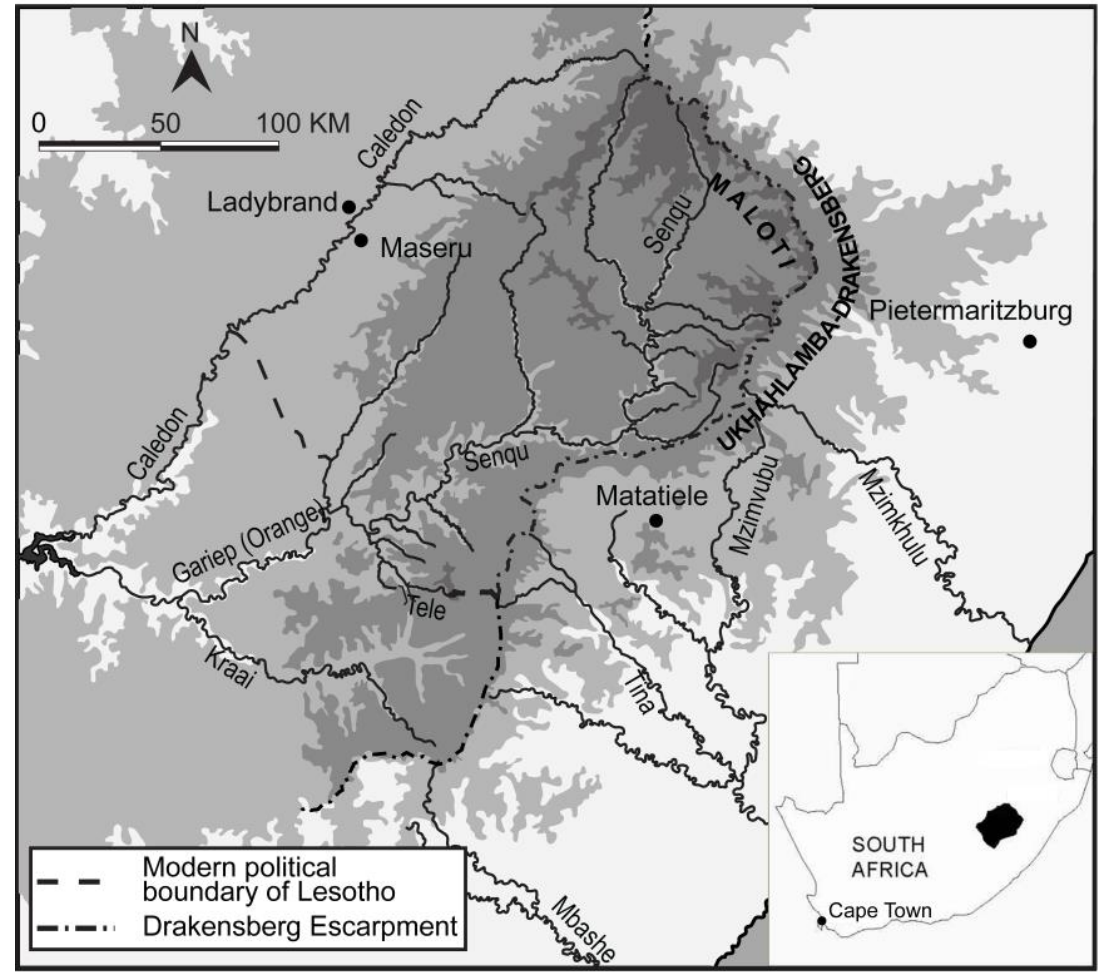


Figure 2 Map of the southern African interior showing places mentioned in the text.

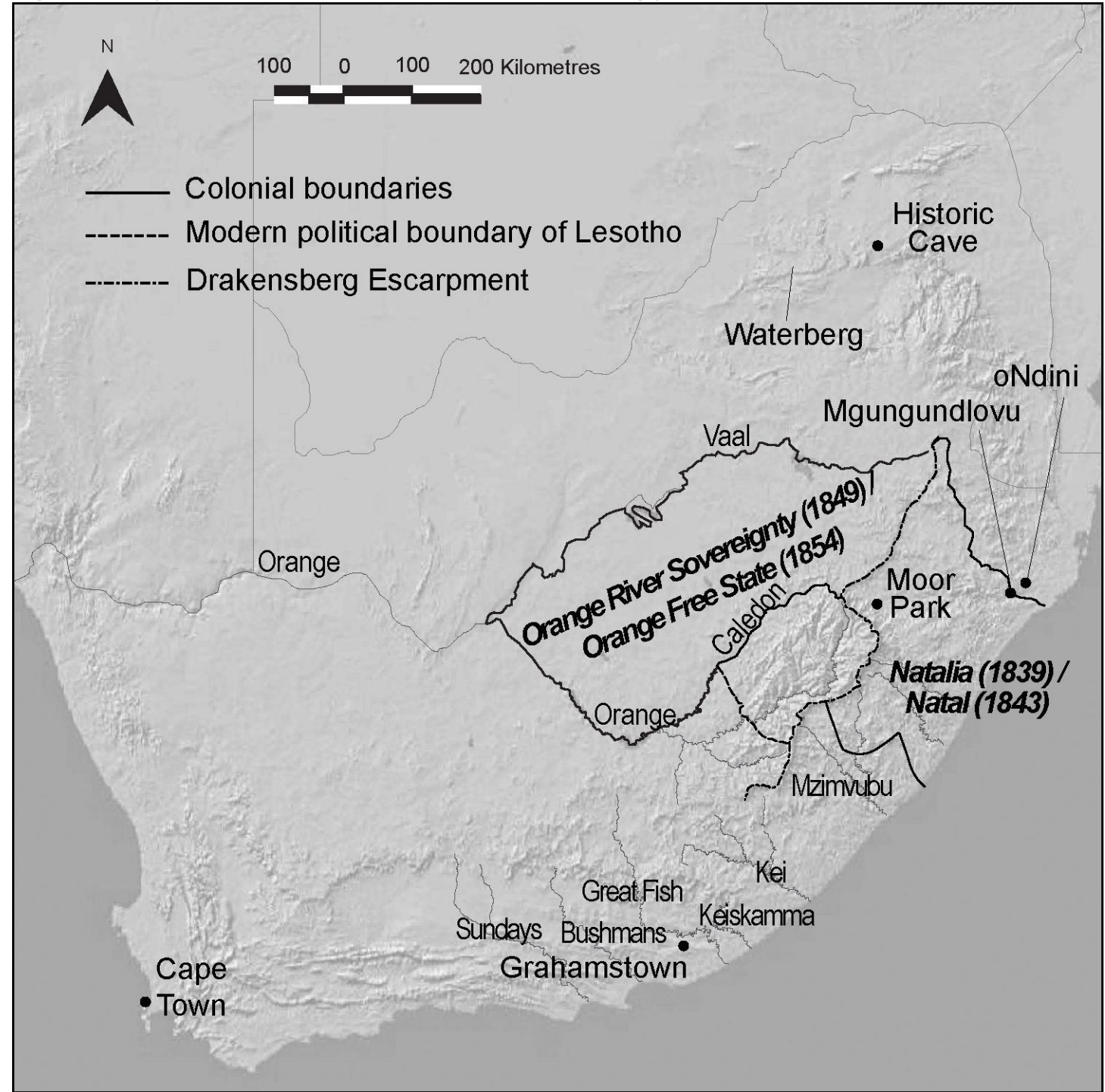


Figure 3 Digital elevation model of the Maloti-Drakensberg Mountains.

Elevation ( $m$ above sea level)

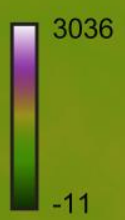
boundary of Lesotho

...... Drakensberg

Escarpment

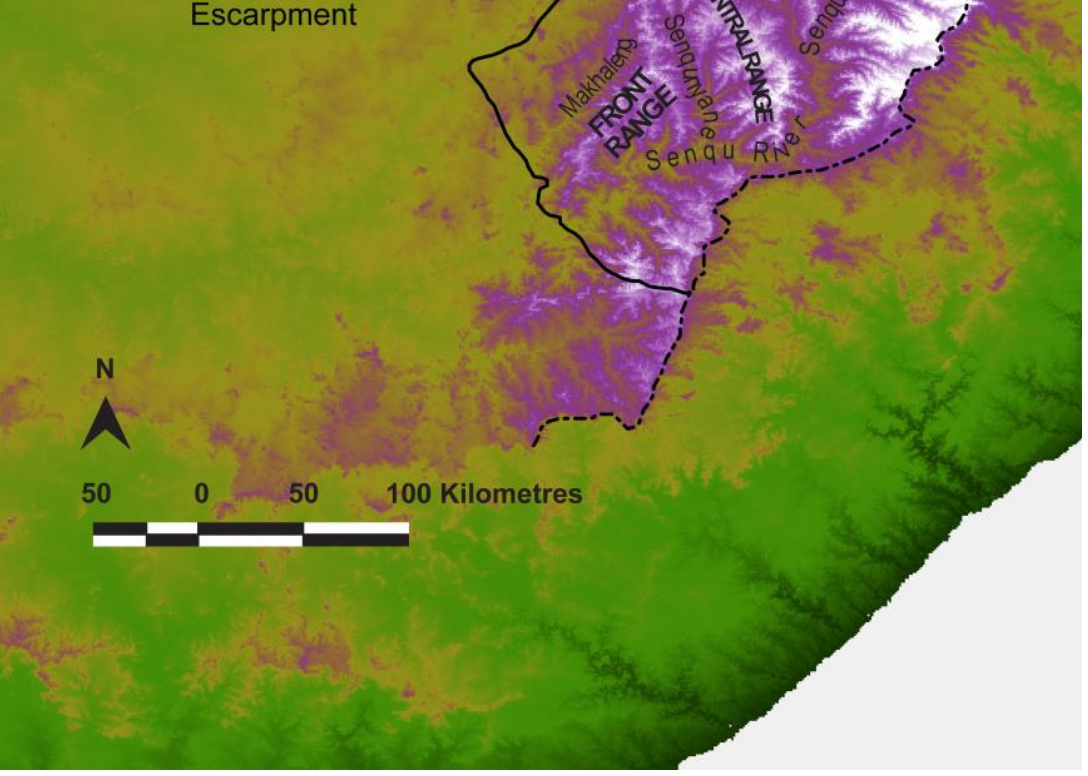

Figure 4 Map of the Maloti-Drakensberg showing places mentioned in the text: 1 Thaba Bosiu (Moshoeshoe's Great Place), 2 Bethesda, 3 Wittebergen Native Reserve, 4 Palmietfontein police station, 5 Quthing magistracy, 6 Bolepeletsa, 7 Masitise Mission 
Station, 8 Mt Moorosi, 9 Qacha's Nek, 10. Sehonghong.

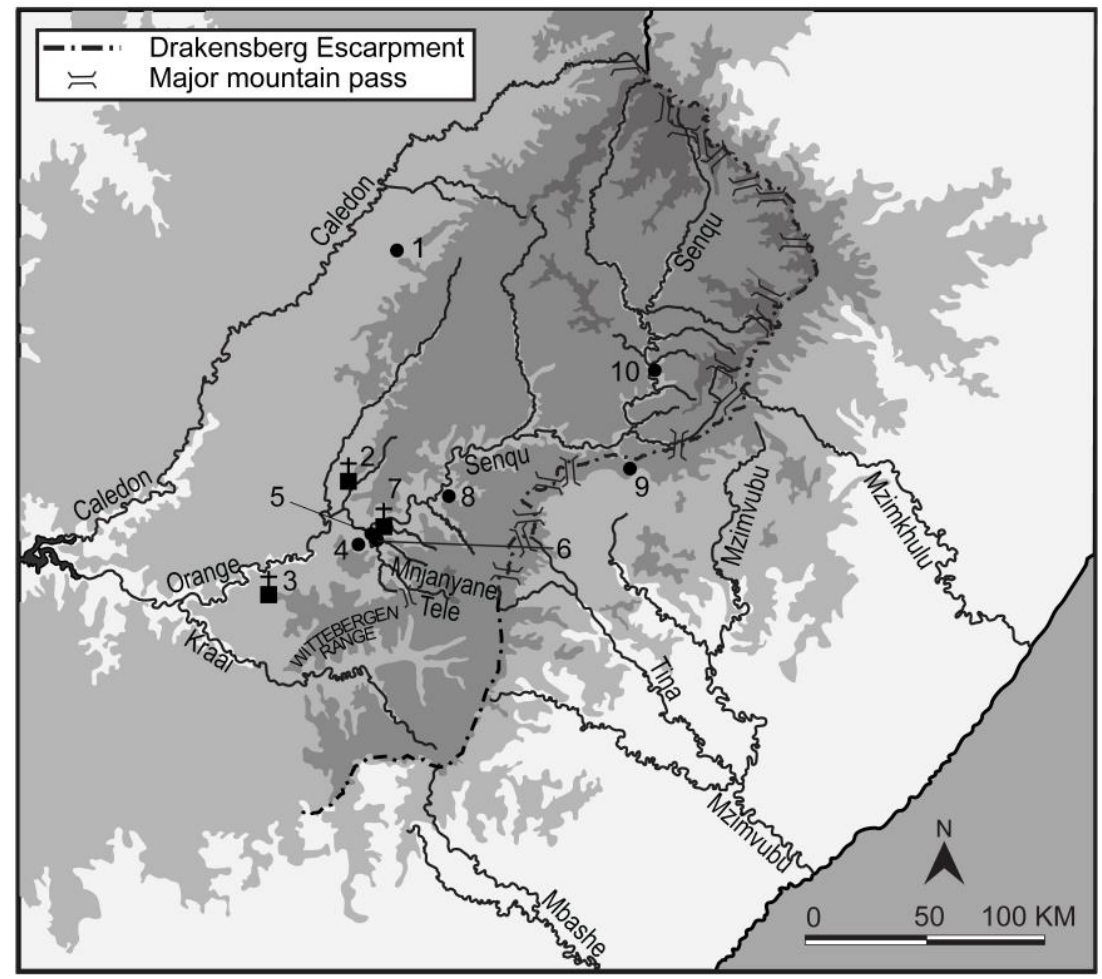

Figure 5 Map showing sites identified in Mnjanyane Valley survey.

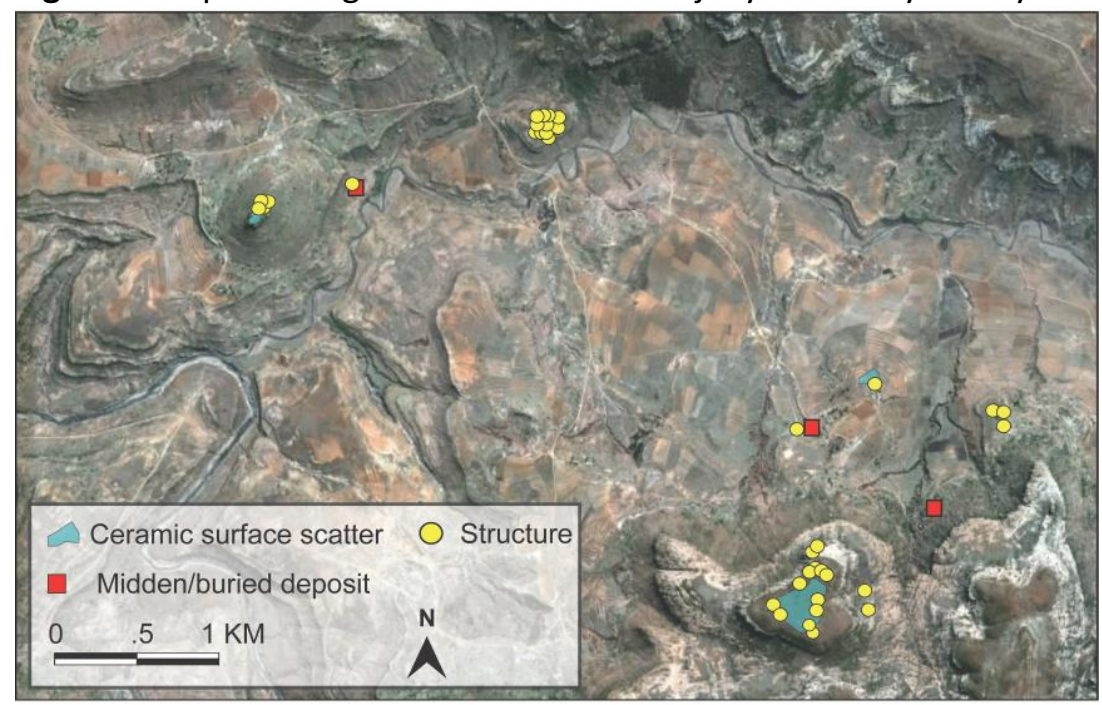


Figure 6 Map showing BaPhuthi settlements: 1 Bethesda, 2 Maphutšeng, 3 Tulumaneng, 4 Lefika la bo Khiba, 5 Wittebergen Mission Station, 6 Litapoleng, 7 Bolepeletsa, 8 Thabana

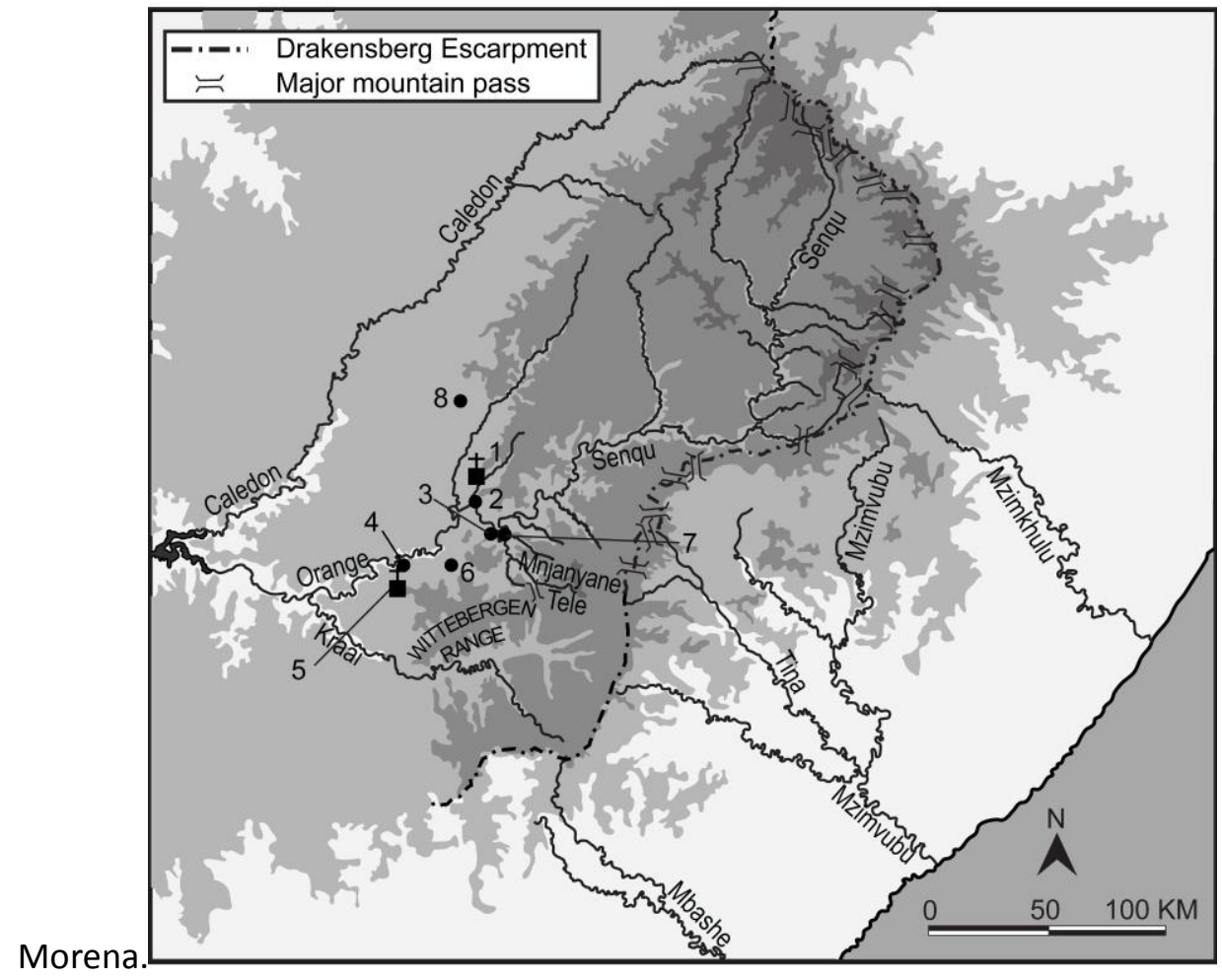

Figure 7 Survey and plan of Mt Moorosi.

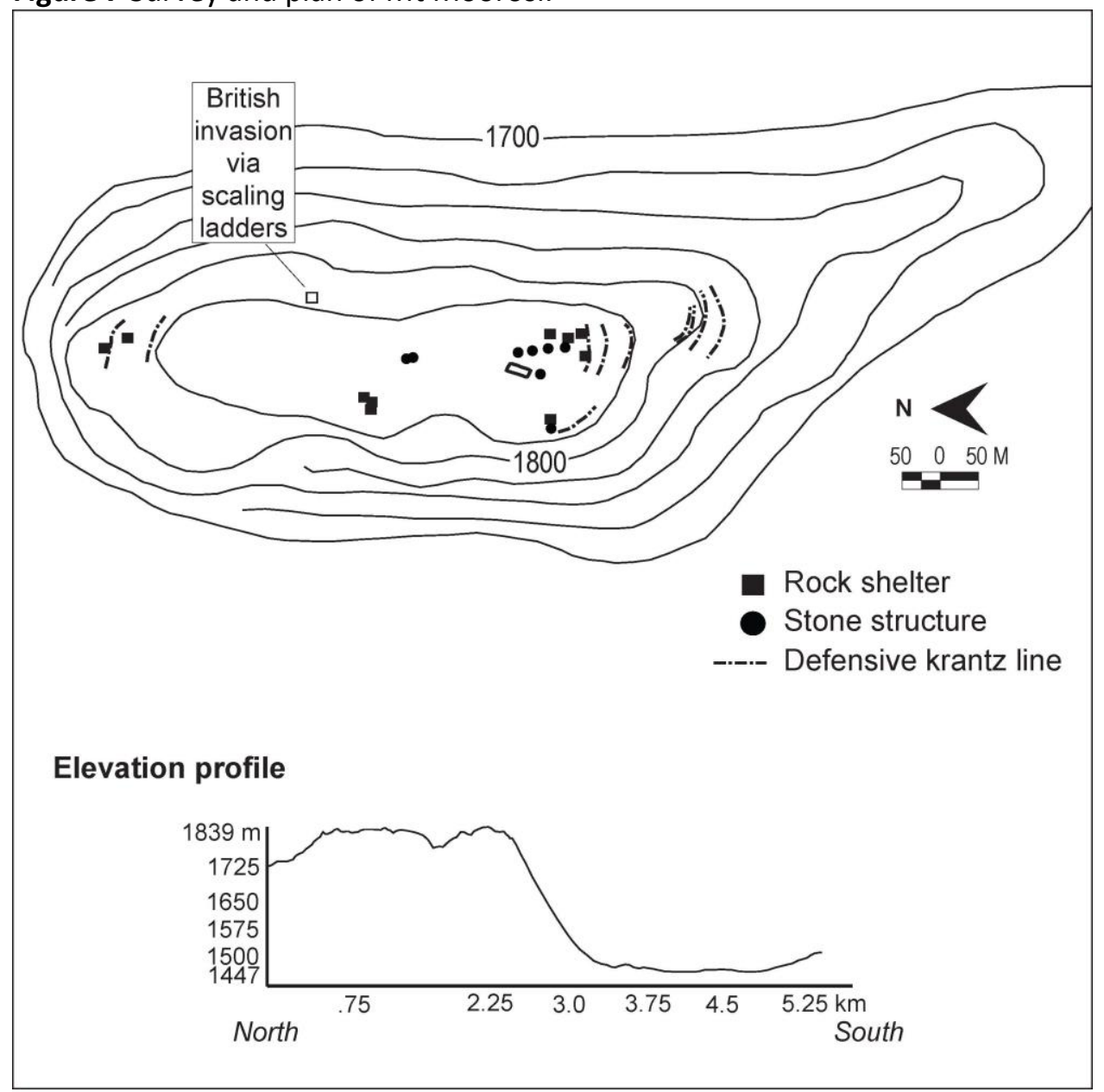




\section{References}

Ashley, C., A. Antonites, \& P. Ditlef Fredriksen, 2016. Mobility and African archaeology: an introduction. Azania: Archaeological Research in Africa 51(4), 417-434.

Atmore, A., 1970. The Moorosi rebellion: Lesotho, 1879, (eds.) R.I Rotberg and A.A. Mazrui, Protest and Power in Black Africa. New York: Oxford University Press, 2-35.

Ayliff, J., 1879. Ayliff's evidence, 17 July 1879, in Minutes of evidence: Committee on Basutoland hostilities. Cape Parliamentary Papers. Cape Town (South Africa). Western Cape Archives: A.6-'79.

Austen, J., 1879. Letter to C. Griffith, 23 February 1879. Cape Town (South Africa). Western Cape Archives: NA 276.

Austen, J. 1880. Letter to C. Griffith, 3 March 1879. Cape Town (South Africa). Western Cape Archives: NA 276.

Beinart, W., 1982. The Political Economy of Pondoland 1860-1930. Johannesburg: Ravan.

Blundell, G., 2004. Nqabayo's Nomansland: San Rock Art and the Somatic Past. Uppsala: Uppsala University.

Bourke, J., 2003. Fear and anxiety: writing about emotion in modern history. History Workshop Journal 55(1), 111-33.

Bradford, H., 2000. Peasants, historians, and gender: a South African case study revisited, 1850-1886. History and Theory 39, 86-110.

Braun, L.F., 2015. Colonial Survey and Native Landscapes in Rural South Africa, 1850-1913: The Politics of Divided Space in the Cape and Transvaal. Leiden: Brill.

Challis, S., 2008. The impact of the horse on the AmaTola 'Bushmen': new identity in the Maloti-Drakensberg Mountains of southern Africa. Unpublished DPhil thesis, University of Oxford.

Challis, S., 2012. Creolisation on the nineteenth-century frontiers of southern Africa: a case study of the AmaTola 'Bushmen' in the Maloti-Drakensberg. Journal of Southern African Studies 38(2), 265-80.

Challis, S., 2016. Re-tribe and resist: the ethnogenesis of a creolised raiding band in response to colonisation, in Tribing and Untribing the Archive: Critical Enquiry into the Traces of the Thukela-Mzimvubu Region from the Early Iron Age until c. 1910, eds. C. Hamilton \& N. Leibhammer. Pietermaritzburg: University of KwaZulu-Natal Press, 282-299.

Dawdy, S.L., 2008. Building the Devil's Empire: French Colonial New Orleans. Chicago: University of Chicago Press.

Douglas, M., 1966. Purity and Danger: An Analysis of Concepts of Pollution and Taboo. London: Routledge and Keegan Paul, Ltd.

Eldredge, E.A., 2007. Power in Colonial Africa: Conflict and Discourse in Lesotho, 1870-1960. Madison (WI): University of Wisconsin Press.

Ellenberger, D.F., 1879. Personal diary of the Moorosi War. Morija (Lesotho). Morija Museum and Archives: D.F. Ellenberger Papers. 
Ellenberger, D.F., ND. History of the Basuto, ancient and modern: Third period. Unpublished manuscript. Morija (Lesotho). Morija Museum and Archives: D.F. Ellenberger Papers.

Ellenberger, D.F. \& J.C. MacGregor, 1912. History of the Basuto, Ancient and Modern. Morija: Morija Museum and Archives.

Esterhuysen, A., 2006. Let the ancestors speak: an archaeological excavation and reevaluation of events prior and pertaining to the 1854 siege of Mugombane, Limpopo Province, South Africa. Unpublished PhD thesis, University of the Witwatersrand.

Esterhuysen, A., 2012. 'A snake cannot have two heads': understanding the historical and recent politics of succession as evidenced in the material and oral record of the Kekana Ndebele. Journal of Southern African Studies 38(2), 319-32.

Etherington, N., 2001. The Great Treks: The Transformation of Southern Africa, 1918-1854. London: Longman.

Etherington, N., 2004. A tempest in a teapot? Nineteenth-century contests for land in South Africa's Caledon Valley and the invention of the mfecane. Journal of African History 45, 20319.

Fleisher, J. \& N. Norman, 2015. Archaeologies of anxiety: the materiality of anxiousness, worry, and fear, in The Archaeology of Anxiety: The Materiality of Anxiousness, Worry, and Fear, eds. J. Fleisher \& N. Norman. New York: Springer, 1-20.

Freud, S., 1946. Civilization and its Discontents. Trans. J. Riviere. London: Hogarth Press.

Freud, S., 1952. A General Introduction to Psychoanalysis. New York: Garden City.

Giblin, J., R. King, \& B. Smith, 2014. Introduction: de-centring ethical assumptions by recentring ethical debates in African archaeology. Azania: Archaeological Research in Africa 49(2), 131-5.

González-Ruibal, A., 2014. An Archaeology of Resistance: Materiality and Time in an African Borderland. Plymouth, UK: Rowman \& Littlefield.

Gosden, C., 2004. Archaeology and Colonialism: Cultural Contact from 5000 BC to the Present. Cambridge: Cambridge University Press.

Griffith, C., 1879. Letter to J. Ayliff, 26 February 1879. Cape Town (South Africa). Western Cape Archives: NA 276.

Haber, A., 2009. Animism, relatedness, life: post-Western perspectives. Cambridge Archaeological Journal 19(3), 418-30.

Hall, M. 1981. Settlement Patterns in the Iron Age of Zululand: An Ecological Interpretation. Oxford: British Archaeological Reports, International Series 119.

Hall, M., 2000. Archaeology and the Modern World: Colonial Transcripts in South Africa and the Chesapeake. Routledge: New York.

Hall, M. \& K. Mack, 1983. The outline of an eighteenth-century economic system in southeast Africa. Annals of the South African Museum 91(2), 163-194.

Hall, M. \& T. Maggs, 1979. Nqabeni, a Later Iron Age site in Zululand. South African Archaeological Society Goodwin Series 3, 159-176.

Hall, S., 1985. Excavations at Rooikrans and Rhenosterkloof: Late Iron Age sites in the Rooiberg area of the Transvaal. Annals of the Cape Provincial Museums 1, 131-210. 
Hall, S., 1995. Archaeological indicators for stress in the western Transvaal region between the seventeenth and nineteenth centuries, in The Mfecane Aftermath: Reconstructive Debates in South African History, ed. C. Hamilton. Johannesburg: Witwatersrand University Press, 307-21.

Hall, S., 1998. A consideration of gender relations in the Late Iron Age 'Sotho' sequence of the western Highveld, South Africa, in Gender in African Prehistory, ed. S. Kent. Walnut Creek: AltaMira, 235-58.

Hall, S., 2012. Identity and political centralisation in the western regions of Highveld, c. 1770c.1830: an archaeological perspective. Journal of Southern African Studies 38(2), 301-18.

Hall, S., M. Anderson, J.C.A. Boeyens, et al, 2008. Towards an outline of the oral geography, historical identity and political economy of the late precolonial Tswana in the Rustenberg Region, in Five Hundred Years Rediscovered: Southern African Precedents and Perspectives, eds. N. Swanepoel, A. Esterhuysen, \& P. Bonner. Johannesburg: Wits University Press, 55-85.

Hämäläinen, P., 2008. The Comanche Empire. New Haven: Yale University Press.

Hamilton, C. (ed.), 1995. The Mfecane Aftermath: Reconstructive Debates in South African Historiography. Johannesburg: Witwatersrand University Press.

Hartnett, A. \& S.L. Dawdy, 2013. The archaeology of illegal and illicit economies. Annual Reviews of Anthropology 42, 37-51.

Hobsbawm, E., 2010. Bandits. New York: The New Press.

How, M., 1930. Notes taken end of November 1930 from Mapote the son of Moorosi at Qacha's Nek. Morija (Lesotho). Morija Museum and Archives: Marion Walsham How Papers.

Huffman, T.N., 1990. Obituary: the Waterberg research of Jan Aukema. South African Archaeological Bulletin 45, 117-9.

Huffman, T.N., 2004. The archaeology of the Nguni past. Southern African Humanities 16, 79111.

Huffman, T.N., 2007. Handbook to the Iron Age: The Archaeology of Pre-Colonial Farming Societies in Southern Africa. Pietermaritzburg: University of KwaZulu-Natal Press.

Hyde, A.F., 2011. Empires, Nations, and Families: A History of the North American West, 1800-1860. Lincoln (NE): Ecco.

Jackson, P. \& J. Everts, 2010. Anxiety as social practice. Environment and Planning 42(11), 2791-806.

King, R., 2014. Voluntary barbarians of the Maloti-Drakensberg: the BaPhuthi chiefdom, cattle raiding, and colonial rule in nineteenth-century southern Africa. Unpublished DPhil thesis, University of Oxford.

King, R., 2015. 'A loyal liking for fair play': Joseph Millerd Orpen and knowledge production in the Cape Colony. South African Historical Journal 67(4), 410-32.

King, R., forthcoming a. Among the headless hordes: missionaries, outlaws, and logics of landscape in the Wittebergen Native Reserve, c. 1850-1879. Journal of Southern African Studies.

King, R., forthcoming b. Cattle, raiding, and disorder in southern African history. Africa. 
King, R., forthcoming c. Mis-apprehensions: outlaws and anxiety in southern Africa's archaeological past, in Anxiety in and about Africa, eds. A. Grant and Y. Pringle. Athens, OH: Ohio University Press.

King, R., C. Arthur, \& P. Mitchell, 2014. Ha Makoanyane: the archaeology and history of colonial transitions in Lesotho. Southern African Humanities

King, R. \& S. Challis, forthcoming. The 'interior world' of the nineteenth-century MalotiDrakensberg Mountains. Journal of African History.

Kopytoff, I., 1987. The internal African frontier: the making of an African political culture, (ed.) I. Kopytoff, The African Frontier: The Reproduction of Traditional African Societies. Bloomington (IN): Indiana University press, 3-84.

Landau, P.S., 2010. Popular Politics in the History of South Africa, 1400-1948. New York: Cambridge University Press.

Lane, P.J., 2011. Possibilities for a postcolonial archaeology in sub-Saharan Africa: indigenous and usable pasts. World Archaeology 43, 7-25.

Lane, P.J., 2016. New directions for historical archaeology in eastern Africa? Journal of African History 57(2), 173-81.

Leselinyana la Lesotho, 1909. Transcript of pitso held 27-9 September 1909. Leselinyana la Lesotho, 2 October 1909. Trans. Tiisetso Pitso and Stephen Gill.

Maggs, T.M.O'C., 1976. Iron Age Communities of the Southern Highveld. Pietermaritzburg: Natal Museum, Occasional Publication 2.

Mallen, L., 2008. Rock art and identity in the north Eastern Cape Province. Unpublished MA thesis, University of the Witwatersrand.

Martindale, A., 2009. Entanglement and tinkering: structural history in the archaeology of the northern Tsimshian. Journal of Social Archaeology 9, 59-91.

McGranaghan, M., 2016. The death of the agama lizard: the historical significances of a multi-authored rock-art site in the Northern Cape (South Africa). Cambridge Archaeological Journal 26(1), 157-79.

Mitchell, P., 2009a. Gathering together a history of the People of the Eland: towards an archaeology of Maloti-Drakensberg hunter gatherers, in The Eland's People: New Perspectives in the Rock Art of the Maloti-Drakensberg Bushmen. Essays in Memory of Patricia Vinnicombe, eds. P. Mitchell \& B. Smith. Johannesburg: Witwatersrand University Press, 99-136.

Mitchell, P., 2009b. Hunter-gatherers and farmers: some implications of 1,800 years of interaction in the Maloti-Drakensberg region of southern Africa. Senri Ethnological Studies $73,15-46$.

Mitchell, P., 2010. Making history at Sehonghong: Soai and the last Bushman occupants of his shelter. Southern African Humanities 22: 149-70.

Mitchell, P., 2013. Contextualising Qing. The Digging Stick 30, 19-21.

Mitchell, P. \& S. Challis, 2008. A 'first' glimpse into the Maloti Mountains: the diary of James Murray Grant's expedition of 1873-74. Southern African Humanities 20, 399-461. 
Mitchell, P. \& G. Whitelaw, 2005. The archaeology of southernmost Africa from c. 2,000 BP to the early 1800s: a review of recent research. Journal of African History 46, 209-41.

Morton, F., 2009. When Rustling Became an Art: Pilane's Kgatla and the Transvaal Frontier 1820-1902. Cape Town: David Philip.

Mucina, L., D.B. Hoare, M.C. Lötter, et al., 2006. Grassland biome, in The Vegetation of South Africa, Lesotho and Swaziland, eds. L. Mucina and M.C. Rutherford. Pretoria: South African National Biodiversity Institute, 348-437.

Mucina, L. \& M.C. Rutherford (eds.), 2006. The Vegetation of South Africa, Lesotho and Swaziland. Pretoria: South African National Biodiversity Institute.

Parkington, J. \& M. Cronin, 1979. The size and layout of Mgungundlovu 1829-38. South African Archaeological Society Goodwin Series 3, 133-48.

Parsons, N., 1995. Prelude to Difaqane in the interior of southern Africa c.1600-c.1822, in The Mfecane Aftermath: Reconstructive Debates in South African History, ed. C. Hamilton. Johannesburg: Witwatersrand University Press, 323-349.

Peires, J.B., 1981. The House of Phalo: History of the Xhosa People in the Days of Their Independence. Johannesburg: Ravan Press.

Plug, I. \& F. Roodt, 1990. The faunal remains from recent excavations at Mgungundlovu. South African Archaeological Bulletin 45, 47-52.

Reid, A., 2016. Constructing history in Uganda. Journal of African History 57(2), 195-207.

Reid, L. \& P. Lane, 2004. African historical archaeology: an introductory consideration of scope and potential, in African Historical Archaeologies, eds. A. Reid and P. Lane. New York: Kluwer/Plenum, 1-32.

Rutherford, M.C., L. Mucina, \& L.W. Powrie, 2011. Biomes and bioregions of southern Africa, in The Vegetation of South Africa, Lesotho and Swaziland, eds. L. Mucina \& M.C. Rutherford. Pretoria: South African National Biodiversity Institute, 30-51.

Sanders, P., 2011. 'Throwing Down White Man': Cape Rule and Misrule in Colonial Lesotho 1871-1884. Morija: Morija Museum and Archives.

Schmidt, P. \& J. Walz, 2007. Silences and mentions in history making. Historical Archaeology 41(4), 129-46.

Schrumpf, C., 1847. Assemblée national à Béthesda, 25 March 1847. Journal des Missions Évangélique, 288-301.

Scott, J.C., 2009. The Art of Not Being Governed: An Anarchist History of Upland Southeast Asia. New Haven (CT): Yale University Press.

Showers, K., 2005. Imperial Gullies: Soil Erosion and Conservation in Lesotho. Athens $(\mathrm{OH})$ : Ohio University Press.

Shepherd, N., 2004. Heading south, looking north: why we need a post-colonial archaeology. Public Archaeology 3: 248-54.

Silliman, S.W., 2005. Culture contact or colonialism? Challenges in the archaeology of native North America. American Antiquity 70, 55-74.

Stahl, A.B., 2001. Making History in Banda: Anthropological Visions of Africa's Past. Cambridge: Cambridge University Press. 
Stahl, A.B., 2002. Colonial entanglements and the practices of taste: an alternative to logocentric approaches. American Anthropologist 104(3), 827-45.

Stahl, A.B., 2009. The archaeology of African history. International Journal of African Historical Studies 42(2), 241-55.

Stapleton, T.J., 2001. Faku: Rulership and Colonialism in the Mpondo Kingdom (c. 17801867). Waterloo (ON): Wilfried Laurier University Press.

Start, J., 1879. Letter to J. Kilner, 1 May 1870. London (United Kingdom). SOAS: Wesleyan Methodist Missionary Society, South Africa Correspondence, Bloemfontein, Fiche Box Number 6 .

Stoler, A.L., 2008. Epistemic politics: ontologies of colonial common sense. The Philosophical Forum 39(3), 349-61.

Stoler, A.L., 2009. Along the Archival Grain: Epistemic Anxieties and Colonial Common Sense. Princeton: Princeton University Press.

Stoler, A.L. \& F. Cooper, 1997. Between metropole and colony: rethinking a research agenda, in Tensions of Empire: Colonial Cultures in a Bourgeois World, eds. F. Cooper \& A.L. Stoler. Berkeley: University of California Press, 1-57.

Tarlow, S., 2012. The archaeology of emotion and affect. Annual Review of Anthropology 41, 169-185.

Theal, G.M., 1883. Basutoland Records, Volumes I and III. Cape Town: W.A. Richards \& Sons.

Theal, G.M., 2002. Basutoland Records, Volumes IV and V, ed. M. Thabane. Roma (Lesotho): Institute for Southern African Studies.

Thomas, N., 1991. Entangled Objects: Exchange, Material Culture, and Colonialism in the Pacific. Cambridge (MA): Harvard University Press.

Thompson, L., 1975. Survival in Two Worlds: Moshoeshoe of Lesotho 1786-1870. Oxford: Clarendon Press.

Thorp, C.R., 2000. Hunter-Gatherers and Farmers: An Enduring Frontier in the Caledon Valley, South Africa. Oxford: Archaeopress.

Voss, B.L., 2005. From casta to Californio: social identity and the archaeology of culture contact. American Anthropologist 107, 461-74.

Voss, B.L., 2008. The Archaeology of Ethnogenesis: Race and Sexuality in Colonial San Francisco. Berkeley: University of California Press.

Voss, B.L., 2015. What's new? Rethinking ethnogenesis in the archaeology of colonialism. American Antiquity 80(4), 655-70.

Voss, B.L. \& E.C. Casella (eds.), 2012. The Archaeology of Colonialism: Intimate Encounters and Sexual Effects. Cambridge: Cambridge University Press.

Vinnicombe, P., 2009. People of the Eland: Rock Paintings of the Drakensberg Bushmen as a Reflection of their Life and Thought. Johannesburg: Wits University Press.

Watson, E.J. \& V. Watson, 1990. 'Of commoners and kings': faunal remains from Ondini. South African Archaeological Bulletin 45, 33-46. 
White, R., 1991. The Middle Ground: Indians, Empires, and Republics in the Great Lakes Region, 1650-1815. Cambridge: Cambridge University Press.

Whitelaw, G., 2008. A brief archaeology of precolonial farming in KwaZulu-Natal, in Zulu Identities: Being Zulu, Past and Present, eds. B. Carton, J. Laband, \& J. Sithole. Scottsville: University of KwaZulu-Natal Press, 47-61.

Whitelaw, G., 2009. 'Their village is where they kill game': Nguni interactions with the San, in The Eland's People: New Perspectives in the Rock Art of the Maloti-Drakensberg Bushmen. Essays in Memory of Patricia Vinnicombe, eds. P. Mitchell \& B. Smith. Johannesburg: Witwatersrand University Press, 139-64.

Whitelaw, G., 2013. Pollution concepts and marriage for the southern African Iron Age. Cambridge Archaeological Journal 23(2), 203-25.

Whitelaw, G., 2015. Economy and cosmology in the Iron Age of KwaZulu-Natal. Unpublished $\mathrm{PhD}$ thesis, University of the Witwatersrand.

Whitelaw, G. \& S. Hall, 2016. Archaeological contexts and the creation of social categories before the Zulu kingdom, in Tribing and Untribing the Archive: Critical Enquiry into the Traces of the Thukela-Mzimkhulu Region from the Early Iron Age until c. 1910, eds. C. Hamilton \& N. Leibhammer. Pietermaritzburg: University of KwaZulu-Natal Press, 146-181.

Wright, J.B., 1971. Bushman Raiders of the Drakensberg, 1840-1870. Pietermaritzburg: University of KwaZulu-Natal Press.

Zappia, N.A., 2014. Traders and Raiders: The Indigenous Worlds of the Colorado Basin, 15401859. Chapel Hill (NC): University of North Carolina Press. 